\title{
Mutu Fisik Organoleptik Pelet Limbah Penetasan dengan Penambahan Bentonit dan Lama Penyimpanan yang Berbeda
}

\section{(Physical Organoleptic Qualities of Hatchery Waste Pellets with Bentonite Addition and Different Storage Time)}

\author{
Rakhmawati YE, Sulistiyanto B, Sumarsih S \\ Fakultas Peternakan dan Pertanian, Universitas Diponegoro, Semarang \\ bsoel10@gmail.com
}

\begin{abstract}
An addition of bentonite as absorbent mineral to the pelletizing process of hatchery waste was expected able to improve and maintain physical-organoleptic quality of pellet product during storage. The experiment was conducted by completely randomized design with factorial pattern $2 \mathrm{x}$ 3 and 3 replications of each combination. The factors were addition of bentonites ( 0 and 3\%) and time lenght of storage (4, 8 and 12 weeks). Parameters observed were organoleptic quality (texture, color, odour and the pellets rupture) and physical quality (durability and hardness). Organoleptic quality evaluations were performed by 15 trained panelists. Data were analyzed by the KruskalWallis Test $\alpha 0.05$, while durability and hardness by the analysis of variance. The results showed that there was no interaction effect between bentonites addition and storage time to the physical organoleptic quality of pellet product. The organoleptic qualities of pellet did not change during storage. Pellet Durability Index (PDI) and hardness of pellets remained high $(>90 \%$ and $5 \mathrm{~kg} / \mathrm{cm}$ ). However, pellet with addition of $3 \%$ bentonite have lower hardness than pellet without the addition of bentonite. It was concluded that $3 \%$ bentonite addition and time of storage up to 12 weeks did not affect the physical-organoleptic quality of hatchery waste pellets.
\end{abstract}

Key Words: Hatchery Waste Pelleted, Bentonite, Storage, Physical-Organoleptic, Quality

\begin{abstract}
ABSTRAK
Penambahan bentonit sebagai mineral absorben pada proses pembuatan pelet limbah penetasan diharapkan mampu meningkatkan dan mempertahankan mutu fisik-organoleptik pelet selama penyimpanan. Penelitian dilakukan menggunakan RAL faktorial $2 \times 3$ sebanyak 3 ulangan untuk masing-masing kombinasi perlakuan. Perlakuan yang diberikan adalah penambahan bentonit (0 dan 3\%) dan lama penyimpanan (4, 8 dan 12 minggu). Parameter yang diamati adalah mutu organoleptik (tekstur, warna, bau dan jumlah pelet pecah) dan mutu fisik (durabilitas dan hardness). Evaluasi mutu organoleptik dilakukan oleh 15 panelis terlatih. Data diuji KruskalWallis $\alpha$ 0,05 sementara durabilitas dan hardness diuji menggunakan analisis ragam. Hasil penelitian menunjukkan bahwa tidak ada pengaruh interaksi antara penambahan bentonit dan waktu penyimpanan terhadap mutu fisik organoleptik. Mutu organoleptik tidak mengalami perubahan selama penyimpanan baik dengan bentonit atau tanpa bentonit. Nilai durabilitas (PDI) dan hardness pelet tergolong tinggi $(>90 \%$ dan $5 \mathrm{~kg} / \mathrm{cm})$ selama penyimpanan. Namun, pelet dengan penambahan $3 \%$ bentonit memiliki nilai hardness yang lebih rendah dibandingkan dengan pelet tanpa penambahan bentonit. Hal ini dapat disimpulkan bahwa penambahan bentonit hingga $3 \%$ dan lama penyimpanan hingga 12 minggu tidak mempengaruhi mutu fisik-organoleptik pelet limbah penetasan.
\end{abstract}

Kata Kunci: Pelet Limbah Penetasan, Bentonit, Penyimpanan, Fisik Organoleptik, Mutu 


\section{PENDAHULUAN}

Limbah penetasan memiliki kandungan nutrisi yang tinggi sehingga dapat dimanfaatkan sebagai bahan pakan alternatif. Kandungan nutrisi dalam limbah penetasan yaitu 33,1\% protein kasar (PK); 29,0\% lemak kasar (LK); 12,1\% serat kasar (SK); 21,5\% abu dan 28,8 MJ/kg gross energi (Glatz et al. 2011). Pemanfaatan limbah penetasan sebagai bahan pakan alternatif belum optimal karena terkendala dengan penampilan fisik dan bau yang tidak menyenangkan. Pelleting merupakan salah satu teknologi pengolahan limbah penetasan untuk memperbaiki mutu dan penampilan limbah penetasan sehingga memudahkan dalam penanganan dan penyimpanan. Mutu bahan pakan atau pakan akan mengalami penurunan seiring dengan lama waktu penyimpanan.

Salah satu upaya untuk mempertahankan mutu pakan adalah menambahkan mineral absorben pada proses pelleting. Mineral absorben seperti zeolit, bentonit, kaolin, kalsium lignosulfat dan sepiolit biasa digunakan pada proses pengolahan pakan, karena dapat memperbaiki struktur pelet, mengikat aflatoksin dan memperbaiki pemanfaatan nutrisi. Bentonit memiliki sifat menyerap zat disekitarnya yang berupa larutan, gas dan penukar kation dan biasa digunakan sebagai bahan penyerap dalam bidang peternakan, perikanan maupun pertanian (Aziz 2009). Bentonit telah banyak digunakan dalam industri peternakan baik sebagai aditif pakan maupun sebagai bahan dalam sanitasi kandang. Rozy (2008) melaporkan bahwa penggunaan bentonit sebanyak 4\% merupakan taraf pemberian optimum untuk meningkatkan mutu fisik pakan dalam bentuk pelet. Retnani et al. (2009) menyatakan bahwa penambahan bentonit dalam pakan bentuk pelet dapat meningkatkan ketahanan pelet. Mutu fisik pakan bentuk pelet meliputi kadar air, ketahanan benturan dan ketahanan gesekan (Saenab et al. 2010) umumnya mengalami perubahan sejalan dengan waktu dan lingkungan selama penyimpanan. Adanya perubahan mutu pakan selama penyimpanan mendorong dilakukannya uji mutu fisik maupun organoleptik pakan yang meliputi warna, tekstur, bau, keutuhan pelet, kekerasan dan durabilitas. Penambahan bentonit diharapkan mampu mengendalikan kadar air pelet selama penyimpanan sehingga dapat menekan perubahan mutu fisik organoleptik. Uji mutu fisik organoleptik pakan pada lama penyimpanan yang berbeda dapat memberikan informasi batas waktu penyimpanan pakan agar ketika didistribusikan kepada konsumen, mutu pakan tetap dapat terjaga.

\section{MATERI DAN METODE}

Penelitian dilakukan di Laboratorium Teknologi Pakan Fakultas Peternakan dan Pertanian, Universitas Diponegoro. Rancangan penelitian yang digunakan adalah Rancangan Acak Lengkap Pola Faktorial $2 \times 3$ dengan 3 ulangan untuk masing masing kombinasi perlakuan. Komponen limbah penetasan yang digunakan adalah $60 \%$ telur gagal menetas, 30\% cangkang telur dan 10\% DOC afkir atau mati. Masing masing bahan tersebut dihaluskan menggunakan blender dicampur rata kemudian ditambah onggok sebanyak $10 \%$ dari ransum dan dicampur rata. Penambahan bentonit sebagai faktor A sebanyak 3\% untuk A1 dan tanpa penambahan bentonit untuk A0 kemudian dicampur rata dan selanjutnya dilakukan pemanasan atau conditioning selama 15 menit. Adonan dicetak menjadi pelet dengan ukuran diameter $6 \mathrm{~mm}$. Pengeringan pelet menggunakan mesin pengering dengan suhu $\pm 40^{\circ}$ selama 24 jam. Pelet yang sudah kering dikemas menggunakan plastik yang ditutup rapat kemudian disimpan pada suhu kamar dengan lama penyimpanan yang berbeda sebagai faktor B yaitu empat minggu (B1), delapan minggu (B2) dan 12 minggu (B3). Penilaian penampilan organoleptik (bentuk, warna, bau dan keutuhan pelet) (Tabel 1) dilakukan oleh 15 orang panelis terlatih dan dilanjutkan dengan Uji Kruskal-Wallis $\alpha$ 0,05 sedangkan durabilitas dan kekerasan pelet diukur menggunakan 
durability pellet tester dan hand hardness tester (Kahl Hardness). Penambahan bentonit pada pelleting limbah penetasan diharapkan mampu mengendalikan kadar air pelet selama penyimpanan sehingga mampu mempertahankan mutu fisik organoleptik pelet limbah penetasan.

Tabel 1. Penentuan skor mutu organoleptik

\begin{tabular}{|c|c|c|c|c|c|}
\hline & Skor & Bentuk & Warna & $\mathrm{Bau}$ & $\begin{array}{c}\text { Jumlah } \\
\text { pelet pecah }\end{array}$ \\
\hline 1 & $\begin{array}{l}\text { Sangat } \\
\text { jelek }\end{array}$ & $\begin{array}{l}\text { Permukaan kasar/tidak rata, } \\
\text { retakan tampak jelas dan } \\
\text { ukuran tidak seragam }\end{array}$ & $\begin{array}{l}\text { Kecokelatan dan } \\
\text { banyak bercak gelap }\end{array}$ & $\begin{array}{l}\text { Bau telur busuk } \\
\text { sangat tajam }\end{array}$ & $>15 \%$ \\
\hline 3 & Jelek & $\begin{array}{l}\text { Permukaan agak tidak rata, } \\
\text { ada tanda retakan, bengkok } \\
\text { dan ukuran tidak seragam }\end{array}$ & $\begin{array}{l}\text { Kurang cerah dan } \\
\text { ada bercak gelap }\end{array}$ & $\begin{array}{l}\text { Berbau amis } \\
\text { dan agak bau } \\
\text { busuk }\end{array}$ & $10-15 \%$ \\
\hline 5 & Baik & $\begin{array}{l}\text { Permukaan halus/rata, ada } \\
\text { retakan halus, bengkok dan } \\
\text { ukuran beberapa seragam }\end{array}$ & $\begin{array}{l}\text { Cerah, kurang } \\
\text { merata dan ada } \\
\text { sedikit bercak gelap }\end{array}$ & $\begin{array}{l}\text { Agak berbau } \\
\text { khas telur/agak } \\
\text { amis }\end{array}$ & $5-10 \%$ \\
\hline 7 & $\begin{array}{l}\text { Amat } \\
\text { baik }\end{array}$ & $\begin{array}{l}\text { Permukaan halus/rata, tidak } \\
\text { ada retakan, lurus, ukuran } \\
\text { seragam }\end{array}$ & $\begin{array}{l}\text { Cerah, merata dan } \\
\text { tidak ada bercak } \\
\text { gelap }\end{array}$ & Tidak berbau & $<5 \%$ \\
\hline
\end{tabular}

Sumber: Sulistiyanto et al. (2016)

Uji mutu fisik dilakukan menggunakan hardness tester dan durability tester. Uji kekerasan pelet atau hardness menggunakan Kahl Hardness tester menurut Franke \& Rey (2006) dilakukan dengan menekan pelet sampai pelet tersebut retak dan diperoleh skala yang tertera pada alat tersebut dalam satuan kilogram. Kahl Hardness tester dioperasikan dengan tangan pada sampel pelet yang digunakan sebanyak 12-20 buah pelet. Uji ketahanan gesekan atau durabilitas pelet merujuk pada Colovic et al. (2010) dilakukan menggunakan pelet durability tester. Pelet dimasukkan kedalam drum yang berputar dengan kecepatan $50 \mathrm{rpm}$ selama 10-15 menit dengan sampel sebanyak $100 \mathrm{~g}$. Pelet kemudian diayak menggunakan ayakan dengan ukuran 0,8 kali diameter pelet yang diukur. Durabilitas pelet (PDI) dinyatakan sebagai perbandingan berat pelet setelah diputar (MPa) dengan berat pelet sebelum diputar ( $\mathrm{MPb})$ kemudian dikalikan dengan $100 \%$ atau dengan rumus sebagai berikut:

$$
\mathrm{PDI}=\frac{\mathrm{MPa}}{\mathrm{MPb}} \times 100 \%
$$

Data durabilitas dan hardness pelet limbah penetasan dianalisis menggunakan analisis ragam untuk mengetahui pengaruh perlakuan. Apabila terdapat pengaruh perlakuan maka dilakukan uji lanjut yaitu Uji Wilayah Ganda Duncan untuk mengetahui perbedaan antar perlakuan. Data responden mutu organoleptik dianalisis menggunakan uji Kruskal-Wallis untuk mengetahui adanya perbedaan respon panelis terhadap mutu organoleptik pelet limbah penetasan.

\section{HASIL DAN PEMBAHASAN}

Data evaluasi mutu organoleptik pelet limbah penetasan disajikan dalam Tabel 2. Data tersebut menunjukkan tidak terdapat pengaruh penambahan bentonit, lama penyimpanan dan interaksi antara penambahan bentonit dan lama penyimpanan terhadap mutu 
organoleptik pelet limbah penetasan baik pada bentuk/tekstur, warna, bau, jumlah pelet pecah maupun kadar air.

Bentuk permukaan rata dengan retakan halus dapat disebabkan adanya tepung bulu yang masih berbentuk serat-serat halus. Mulia \& Maryanto (2014) melaporkan bahwa pakan dengan bahan baku yang mengandung tepung bulu cenderung berserat karena meskipun bulu ayam sudah dibuat tepung dan difermentasi, bulu ayam tidak bisa memiliki bentuk yang halus. Bulu ayam yang terdapat pada DOC, tidak memiliki bentuk halus meskipun sudah dibuat tepung. Aslamsyah \& Karim (2012) menyatakan bahwa tekstur pelet dapat dilihat dari permukaan yang halus, berlubang atau berserat yang dapat dipengaruhi oleh kehalusan bahan baku atau ukuran partikel bahan baku binder yang digunakan dan jumlah serat dalam bahan. Warna pelet limbah penetasan yaitu cokelat cerah kurang merata dengan sedikit bercak gelap berasal dari bahan baku yaitu tepung cangkang telur, telur gagal menetas dan daging DOC afkir memiliki warna cokelat muda hingga merah ditambah dengan tepung onggok berwarna cokelat. Penambahan bentonit tidak memberikan pengaruh terhadap warna pelet karena bentonit memiliki warna putih krem. Retnani et al. (2009) menyatakan bahwa warna pellet dengan penambahan bentonit menyerupai warna ransum basal karena bentonit memiliki warna putih krem. Warna pelet baik tanpa atau dengan penambahan bentonit selama penyimpanan tidak mengalami perubahan. Menurut Ahmad (2009) bahan pakan yang mengalami perubahan warna menjadi kehijauan, kehitaman dan bulukan menunjukan bahan pakan tersebut terserang jamur. Pertumbuhan jamur dipengaruhi oleh kadar air selama penyimpanan. Kadar air pelet limbah penetasan relatif rendah dengan kondisi penyimpanan yang tertutup rapat sehingga sangat kecil kemungkinan ditumbuhi jamur.

Bau busuk pada limbah penetasan disebabkan oleh adanya gas ammonia yang terlepas akibat adanya kerusakan protein. Proses pelleting membantu mengurangi bau ammonia akibat adanya conditioning dan proses pengeringan sehingga ammonia yang terdapat dalam limbah penetasan hilang. Bau khas telur atau agak amis yang timbul dapat diakibatkan oleh bahan baku pelet yang berupa telur gagal menetas. Jumlah pelet pecah relatif kecil karena pelet limbah penetasan memiliki nilai durabilitas yang cukup tinggi (Tabel 3). Komponen utama pelet limbah penetasan yang berupa protein menyebabkan adanya denaturasi protein sehingga menyebabkan ikatan antar partikel lebih kuat. Selain itu, terdapat onggok yang masih mengandung pati mengalami gelatinisasi. Adanya denaturasi protein dan gelatinisasi pati ini menyebabkan tekstur pelet limbah penetasan lebih kompak.

Data pengukuran durabilitas pelet limbah penetasan disajikan pada Tabel 3. Data tersebut menunjukan bahwa tidak terdapat pengaruh penambahan lama penyimpanan, penambahan bentonit dan interaksi antara penambahan bentonit dan lama penyimpanan terhadap nilai durabilitas pelet limbah penetasan. Nilai durabilitas yang dihasilkan tergolong tinggi yaitu lebih dari 80\%. Tabil \& Sokhansanj (1996) menyatakan bahwa nilai durabilitas pelet dikatakan rendah apabila kurang dari $70 \%$, nilai durabilitas pelet dikatakan sedang apabila diantara 70-80\% dan nilai durabilitas dikatakan tinggi apabila nilainya lebih dari $80 \%$. Hal ini dapat disebabkan oleh bahan baku pelet yang berupa protein, serat-serat yang berasal dari bulu DOC dan zat pati yang berasal dari onggok.

Thomas et al. (1997) menyatakan bahwa pati memiliki beberapa fungsi diantaranya sebagai agen pengikat (binding agent). Pati yang diberi perlakuan pemanasan akan mengalami proses gelatinisasi yang mampu merekatkan antar partikel bahan penyusun pelet. Loar \& Corzo (2011) menjelaskan bahwa gelatinisasi terjadi apabila zat pati yang mengalami pemanasan dan kandungan air yang cukup akan mengalami kerusakan rantai penyusun awal dan apabila telah dingin akan membentuk rantai baru yang saling merekat. Abdollahi et al. (2013) menyatakan bahwa protein yang terdenaturasi memungkinkan 
Tabel 2. Skor mutu organoleptik* pelet limbah penetasan pada penyimpanan yang berbeda

\begin{tabular}{|c|c|c|c|c|c|}
\hline \multirow{2}{*}{ Kriteria } & \multirow{2}{*}{ Bentonit (\%) } & \multicolumn{3}{|c|}{ Lama penyimpanan (minggu) } & \multirow{2}{*}{ Rata-rata } \\
\hline & & 4 & 8 & 12 & \\
\hline \multirow[t]{3}{*}{ Bentuk/tekstur } & 0 & 3,00 & 5,00 & 5,00 & 4,33 \\
\hline & 3 & 3,00 & 5,00 & 5,00 & 4,33 \\
\hline & Rata-rata & 3,00 & 5,00 & 5,00 & \\
\hline \multirow[t]{3}{*}{ Warna } & 0 & 3,00 & 3,00 & 5,00 & 3,67 \\
\hline & 3 & 5,00 & 3,00 & 5,00 & 4,33 \\
\hline & Rata-rata & 4,00 & 3,00 & 5,00 & \\
\hline \multirow[t]{3}{*}{ Bau } & 0 & 5,00 & 5,00 & 5,00 & 5 \\
\hline & 3 & 5,00 & 5,00 & 5,00 & 5 \\
\hline & Rata-rata & 5,00 & 5,00 & 5,00 & \\
\hline \multirow[t]{3}{*}{ Jumlah pelet pecah } & 0 & 5,00 & 5,00 & 5,00 & 5,00 \\
\hline & 3 & 3,00 & 5,00 & 5,00 & 4,33 \\
\hline & Rata-rata & 4,00 & 5,00 & 5,00 & \\
\hline \multirow[t]{3}{*}{ Kadar air } & 0 & 4,87 & 3,76 & 3,80 & 4,14 \\
\hline & 3 & 4,62 & 4,07 & 3,98 & 4,22 \\
\hline & Rata-rata & 4,74 & 3,91 & 3,89 & \\
\hline
\end{tabular}

*Modus dari penilaian 15 panelis diuji dengan Uji Kruskal-Wallis $\alpha$ 0,05; **Klasifikasi skor mutu organoleptik merujuk pada Sulistiyanto et al. (2016)

Tabel 3. Rata-rata nilai durabilitas (PDI)* pelet limbah penetasan dengan perlakuan penambahan bentonite dan waktu penyimpanan

\begin{tabular}{lcccc}
\hline \hline \multirow{2}{*}{$\begin{array}{l}\text { Penambahan } \\
\text { Bentonit (\%) }\end{array}$} & \multicolumn{3}{c}{ Lama penyimpanan (minggu) } & Rata-rata \\
\cline { 2 - 4 } & 4 & 8 & 12 & \\
\cline { 2 - 4 } 0 & 98,46 & 98,24 & 98,87 & $98,52^{\mathrm{a}}$ \\
3 & 98,25 & 99,19 & 98,58 & $98,67^{\mathrm{a}}$ \\
\hline Rata-rata & $98,35^{\mathrm{a}}$ & $98,71^{\mathrm{a}}$ & $98,72^{\mathrm{a}}$ & \\
\hline
\end{tabular}

${ }^{\text {a}}$ Superskrip yang sama pada kolom atau baris yang sama menunjukkan tidak terdapat perbedaan perlakuan $(\mathrm{P}>0,05) ; *$ Merujuk pada Colovic et al. (2010)

terjadinya gelling yang kuat yang membuat pelet lebih durable. Ikatan antar partikel penyusun pelet yang kuat menjadikan pellet lebih durable sehingga nilai durabilitasnya tinggi. Proses denaturasi protein dan gelatinisasi pati terjadi karena adanya pemanasan yang dalam penelitian ini adalah proses conditioning. Skoch et al. (1981) menyatakan bahwa durabilitas pelet dapat dipengaruhi oleh proses conditioning yang menghasilkan uap panas. Uap panas tersebut membentuk formasi ikatan hidrogen antara molekul air dan protein hidofilik yang terkandung pada bahan penyusun pelet.

Tabel 4 menunjukkan tidak terdapat pengaruh interaksi antara penambahan bentonit dan lama penyimpanan terhadap hardness pelet limbah penetasan. Lama penyimpanan tidak memberikan pengaruh terhadap nilai hardness pellet limbah penetasan tetapi penambahan $3 \%$ bentonit memberikan pengaruh terhadap nilai hardness $(\mathrm{P}<0,05)$. Pelet yang dibuat dengan penambahan $3 \%$ bentonit memiliki rata-rata nilai hardness yang lebih 
rendah yaitu $5,11 \mathrm{~kg}$ dibandingkan pelet yang dibuat tanpa penambahan bentonit yaitu $5,40 \mathrm{~kg}$. Widiyastuti et al. (2004) melaporkan bahwa rata-rata nilai hardness pelet dengan penambahan $3 \%$ bentonit 6,02-9,68 kg dengan bahan berupa hijauan. Nilai hardness dapat dipengaruhi oleh beberapa faktor diantaranya penggunaan sampel pelet selama pengukuran. Pengukuran hardness dapat dipengaruhi oleh beberapa faktor diantaranya variasi panjang pelet yang berbeda, perbedaan tekanan yang diterima dan adanya keretakan pada pelet. Hardness pelet dapat dipengaruhi oleh beberapa hal diantaranya komposisi bahan, binder yang digunakan dan proses conditioning.

Tabel 4. Rata-rata nilai hardness* pelet limbah penetasan dengan perlakuan penambahan bentonit dan waktu penyimpanan

\begin{tabular}{lcccc}
\hline \hline \multirow{2}{*}{$\begin{array}{l}\text { Penambahan } \\
\text { Bentonit }(\%)\end{array}$} & \multicolumn{3}{c}{ Lama Penyimpanan (minggu) } & \multirow{2}{*}{ Rata-rata } \\
\cline { 2 - 4 } & 4 & 8 & 12 & \\
\cline { 2 - 4 } 0 & 5,48 & 5,40 & 5,33 & $5,40^{\mathrm{a}}$ \\
3 & 5,18 & 5,13 & 5,02 & $5,11^{\mathrm{b}}$ \\
\hline Rataan & $5,33^{\mathrm{a}}$ & $5,26^{\mathrm{a}}$ & $5,18^{\mathrm{a}}$ & \\
\hline
\end{tabular}

${ }^{\mathrm{a}, \mathrm{b}}$ Superskrip yang berbeda pada kolom atau baris yang sama menunjukkan terdapat perbedaan pengaruh perlakuan $(\mathrm{P}<0,05)$; *Diukur menggunakan Kahl Hardness Tester

Durabilitas, hardness dan mutu organoleptik pelet dapat dipengaruhi oleh bahan baku yang digunakan dan proses selama pengolahan. Penambahan bentonit belum berpengaruh terhadap mutu fisik organoleptik pelet limbah penetasan. Hal ini kemungkinan diakibatkan oleh penambahan bentonit yang terlalu sedikit dan bentonit masih dalam bentuk mineral alam. Penggunaan bentonit sebagai absorben, dapat dilakukan perlakuan pendahuluan yaitu aktivasi melalui fisik (pemanasan/tanur) atau kimiawi (asam kuat) untuk meningkatkan kapasitas absorbsinya. Lama penyimpanan belum memberikan pengaruh yang signifikan dapat dipengaruhi oleh kadar air yang rendah dan kondisi penyimpanan yang tertutup rapat dengan kondisi suhu dan kelembaban ruang.

\section{KESIMPULAN}

Dapat disimpulkan bahwa penambahan bentonit hingga 3\% dan lama penyimpanan hingga 12 minggu tidak memberikan pengaruh terhadap mutu fisik organoleptik pelet limbah penetasan.

\section{UCAPAN TERIMA KASIH}

Ucapan terima kasih disampaikan kepada Laboratorium Teknologi Pengolahan Pakan, Fakultas Peternakan dan Pertanian, Universitas Diponegoro yang telah memberikan fasilitas selama pelaksanaan, Rektor UNDIP atas dukungan dana melalui hibah kompetitif penelitian mahasiswa, serta Muhammad Sudarwanto, Muhammad Khoiruddin, Mega Hardianti, Atiya Inayati dan Bima Siswoaji atas kerja samanya dalam pelaksanaan penelitian. 


\section{DAFTAR PUSTAKA}

Abdollahi MR, Ravindran V, Svihus B. 2013. Pelleting of broiler diets: An overview with emphasis on pellet quality and nutritional value. Anim Feed Sci Technol. 179:1-23.

Ahmad. 2009. Cemaran kapang pada pakan dan pengendaliannya. J Litbang Pertanian. 28:15-22.

Aslamsyah S, Karim MY. 2012. Uji organoleptik, fisik dan kimiawi pakan buatan untuk ikan bandeng yang disubtitusi dengan tepung cacing tanah (Lumbricus sp). J Akuakultur Indonesia. $11: 124-131$

Aziz M. 2009. Ruang lingkup penelitian pengolahan dan pemanfaatan mineral dalam menunjang prioritas kebutuhan nasional. J Bahan Galian Industri. 5:1-14.

Colovic R, Vukmirovic D, Matulaitis R, Bliznikas S, Juškiene V, Levic J. 2010. Effect of die channel press way length on physical quality of pelleted cattle feed. Food Feed Res. 1:1-6.

Franke M, Rey A. 2006. Improving pellet quality and efficiency. Feed Tech. 10:12-15.

Glatz P, Miao, Rodda B. 2011. Handling and treatment of poultry hatchery waste: A review. Sustainability. 3:216-237.

Loar RE, Corzo A. 2011. Effects of feed formulation on feed manufacturing and pellet quality characteristics of poultry diets. World Poult Sci J. 67:19-27.

Mulia DS, Maryanto H. 2014. Uji fisik dan kimiawi pakan ikan yang menggunakan bahan perekat alami. Dalam: Irsyad S, penyunting. Pengembangan Sumber Daya Menuju Masyarakat Madani Berkearifan Lokal. Prosiding Seminar Hasil Penelitian LPPM Universitas Muhammadiyah Purwokerto. Purwokerto, 6 September 2014. Purwokerto (Indonesia): Universitas Muhammadiyah Purwokerto. hlm. 25-33.

Retnani Y, Harmiyanti Y, Fibrianti DAP, Herawati L. 2009. Pengaruh penggunaan perekat sintetis terhadap ransum ayam broiler. J Agripet. 9:1-9.

Rozy EJE. 2008. Pengaruh penambahan bentonit dan air panas terhadap sifat fisik ransum bentuk pellet [Skripsi]. [Bogor (Indonesia)]: Institut Pertanian Bogor.

Saenab A, Laconi EB, Retnani Y, Mas'ud MS. 2010. Evaluasi kualitas pelet ransum komplit yang mengandung produk samping udang. JITV. 15:31-39.

Skoch ER, Behnke KC, Doyoe CW, Blinder SF. 1981. The effect of steam-conditioning rate on the pelleting process. Anim Feed Sci Technol. 6:83.

Sulistiyanto B, Utama CS, Sumarsih S. 2016. Effect of administering zeolite on the physical performance of pellet product contained chickens hatchery wastes. In: Yulistiani D, Wardhana AH, Inounu I, Bahri S, Iskandar S, Wina E, Ginting SP, Tarigan S, Tiesnamurti B, Romjali E, Herawati T, Anggraeny YN, Shanmugavelu S, Aquino DL, editors. Promoting Livestock and Veterinary Technology for Sustainable Rural Livestock Development. Proceedings of International Seminar on Livestock Production and Veterinary Technology. Denpasar, 10-12 $2^{\text {th }}$ August 2016. Bogor (Indonesia): Puslitbangnak. p. 415-421.

Tabil LJr, Sokhansanj S. 1996. Process conditions affecting the physical quality of alfalfa pellet. Appl Eng Agric. 12:345-350.

Thomas M, van Vliet T, van der Poel AFB. 1997. Physical quality of pelleted animal feed 3. Contribution of feedstuff component. Anim Feed Sci Technol. 70:59-78.

Widiyastuti T, Prayitno CH, Munasik. 2004. Kajian kualitas fisik pellet pakan komplit dengan sumber hijauan dan binder yang berbeda. Anim Prod. 6:43-48. 


\section{DISKUSI}

\section{Pertanyaan}

1. Apakah bentonit itu?

2. Apakah pelet limbah penetasan yang dihasilkan berbau?

3. Skor organoleptik yang disajikan, bagaimana artinya?

4. Kenapa penyimpanan dan penambahan bentonit tidak memberikan pengaruh?

\section{Jawaban}

1. Bentonit merupakan batuan mineral yang dapat dimanfaatkan sebagai mineral adsorben untuk memperbaiki mutu fisik pakan bentuk pelet.

2. Pengolahan limbah penetasan menjadi bentuk pelet bertujuan untuk memperbaiki penampilan fisik dari limbah penetasan. Bau amis dan busuk dari limbah penetasan dapat dihilangkan melalui pengolahan pelet limbah penetasan.

3. Skor penampilan organoleptik yang semakin tinggi menunjukkan mutu organoleptik pelet limbah penetasan semakin baik.

4. Penambahan bentonit dan lama penyimpanan tidak memberikan pengaruh terhadap mutu fisik organoleptik pelet limbah penetasan. Tidak adanya pengaruh bentonit dapat diakibatkan oleh jumlah penambahan yang terlalu sedikit sehingga kemampuan absorbennya kurang maksimal. Faktor berikutnya, bentonit yang digunakan tidak mengalami aktivasi dimana aktivasi mineral absorben dengan tanur/pemanasan maupun secara kimia dngan perendaman asam kuat dapat meningkatkan kemampuan absorben dari mineral bentonit. Metode penyimpanan yang dilakukan selama penelitian adalah dengan menyimpan pelet dalam kondisi yang tertutup rapat dan kadar air pelet yang rendah, sehingga kemungkinan perubahan fisik organoleptiknya sangat rendah. 